ORNL/CON-398

ENERGY DIVISION

\title{
IRP AND THE ELECTRICITY INDUSTRY OF THE FUTURE: WORKSHOP RESULTS
}

BRUCE TONN, ERIC HIRST, AND DOUGLAS BAUER

September 1994

Sponsored by

Office of Energy Efficiency and Renewable Energy

U.S. Department of Energy

OAK RIDGE NATIONAL LABORATORY

Oak Ridge, Tennessee 37831

managed by

MARTIN MARIETTA ENERGY SYSTEMS, INC.

for the

U.S. DEPARTMENT OF ENERGY

under contract No. DE-AC05-840R21400 


\section{DISCLAIMER}

This report was prepared as an account of work sponsored by an agency of the United States Government. Neither the United States Government nor any agency thereof, nor any of their employees, make any warranty, express or implied, or assumes any legal liability or responsibility for the accuracy, completeness, or usefulness of any information, apparatus, product, or process disclosed, or represents that its use would not infringe privately owned rights. Reference herein to any specific commercial product, process, or service by trade name, trademark, manufacturer, or otherwise does not necessarily constitute or imply its endorsement, recommendation, or favoring by the United States Government or any agency thereof. The views and opinions of authors expressed herein do not necessarily state or reflect those of the United States Government or any agency thereof. 


\section{DISCLAIMER}

Portions of this document may be illegible in electronic image products. Images are produced from the best available original document. 


\section{CONTENTS}

Page

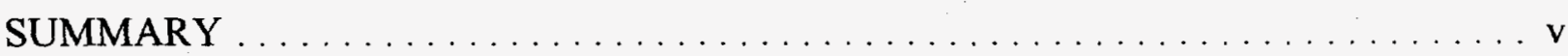

LIST OF ACRONYMS $\ldots \ldots \ldots \ldots \ldots \ldots \ldots \ldots \ldots \ldots \ldots \ldots \ldots$

1. INTRODUCTION $\ldots \ldots \ldots \ldots \ldots \ldots \ldots \ldots \ldots \ldots \ldots \ldots \ldots \ldots \ldots$

2. WORKSHOP METHODOLOGY $\ldots \ldots \ldots \ldots \ldots \ldots \ldots \ldots \ldots \ldots \ldots$

3. WHOLESALE-COMPETITION SCENARIO $\ldots \ldots \ldots \ldots \ldots \ldots \ldots \ldots \ldots$

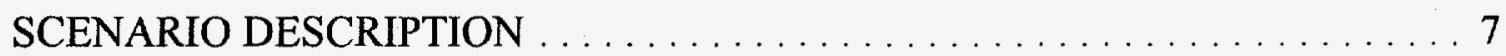

PLANNING AND RESEARCH ISSUES $\ldots \ldots \ldots \ldots \ldots \ldots \ldots \ldots$

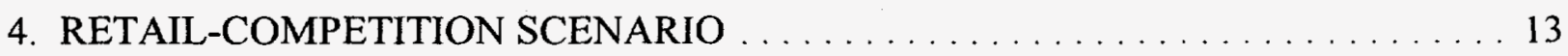

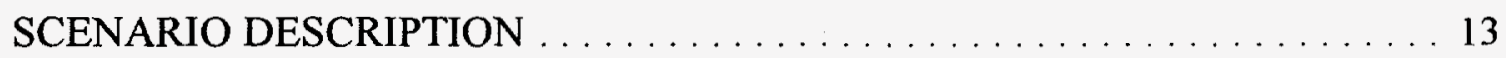

PLANNING AND RESEARCH ISSUES $\ldots \ldots \ldots \ldots \ldots \ldots \ldots \ldots \ldots$

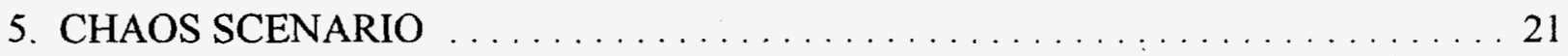

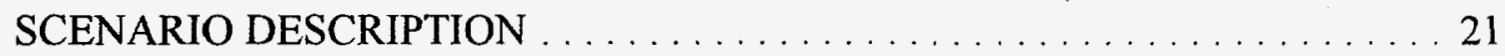

PLANNING AND RESEARCH ISSUES $\ldots \ldots \ldots \ldots \ldots \ldots \ldots \ldots \ldots$

6. RESEARCH AND POLICY-ANALYSIS QUESTIONS . . . . . . . . . . . 29

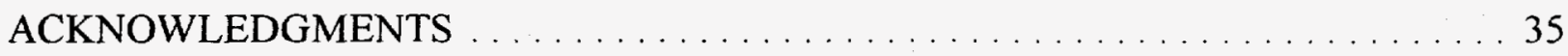

APPENDICES

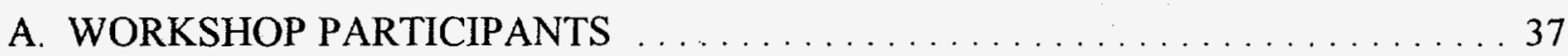

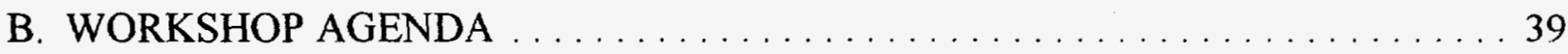





\section{SUMMARY}

During the next several years, the U.S. electricity industry is likely to change dramatically. Instead of an industry dominated by vertically integrated companies that are regulated primarily by state public utility commissions, we may see an industry with many more participants and less regulation. These new participants may include independent power producers, entities that dispatch and control power plants on a real-time basis, entities that build and maintain transmission networks, entities that build and maintain distribution systems and also sell electricity and related to services to some retail customers, and a variety of other organizations that sell electricity and other services to retail customers. Because markets are intended to be the primary determinant of success, the role of state and federal regulators might be less than it has been in the past.

During the past decade, utilities and state regulators have developed new ways to meet customer energy-service needs, called integrated resource planning (IRP). IRP provides substantial societal benefits through the consideration and acquisition of a broad array of resources, including renewables and demand-side management (DSM) programs as well as traditional power plants; explicit consideration of the environmental effects of electricity production and transmission; public participation in utility planning; and attention to the uncertainties associated with different resources, future demands for electricity, and other factors.

IRP might evolve in different ways as the electricity industry is restructured (Table S-1). To explore these issues, we ran a Workshop on IRP and the Electricity Industry of the Future in July 1994. This report presents the wisdom and experience of the 30 workshop participants. To focus discussions, we created three scenarios to represent a few of the many ways that the electricity industry might develop. Workshop participants refined the scenarios and then, for each one, examined the needs for planning as well as research and policy-analysis topics that require more attention.

The wholesale-competition scenario (the one most similar to today's industry structure) features vertically integrated utilities that purchase much of their supply from independent power producers. Although retail wheeling does not exist in this scenario, the possibility that large customers might leave the system spurs utilities to cut costs. State regulators adopt performancebased regulation. This approach, involving either price or revenue caps, further encourages utilities to cut costs and provides them with considerable flexibility to negotiate alternative prices with those customers that have choices. This approach also reduces the frequency and complexity of rate cases. 


\begin{tabular}{lll}
\hline & \multicolumn{1}{c}{ Traditional IRP } & \multicolumn{1}{c}{ Competition } \\
\hline Industry focus & Least-cost energy service & Lowest price \\
Planning goal & Minimize societal cost & Maximize earnings \\
Planning horizon & Long term & Short term \\
Strategy & Diversity & Competition \\
Constituency & Public and private & Private \\
Prices & Cost based & Market based \\
Risk & Shared & Individual firms \\
Public participation & Yes & No \\
DSM driver & Utility & Prices \\
Externalities & Included & Excluded \\
\hline
\end{tabular}

In this scenario, IRP is similar to that practiced today. The key differences are that planning horizons are much shorter, utilities primarily purchase power rather than build power plants, transmission and distribution planning are more important and more complicated, and the plans that utilities submit to regulatory commissions are shorter and simpler.

The retail-competition scenario involves de-integration of utilities. Separate organizations own and operate power plants, run control centers, build and maintain transmission systems, and build and maintain distribution systems. The local distribution companies, as well as other organizations, sell electricity and related services to retail customers. Thus, retail wheeling is a key element of this scenario. The control centers schedule, dispatch, and control power plants and the transmission system on a second-to-second basis. Generating companies contract to provide energy and capacity to distribution companies independent of the control center's engineering and reliability operations. Thus, the flows of money and electrons are independent in this scenario.

The decentralized nature of the industry under the retail-competition scenario makes the integrated part of IRP difficult to maintain. Although all the traditional elements of IRP remain, they are conducted by disparate entities that have little incentive to cooperate with each other. Thus, distribution-system, transmission-system, generation-expansion, system-reliability, and environmental planning are conducted by different organizations. To the extent that integrated resource planning is needed, government agencies (e.g., regulatory commissions or state energy offices) may develop such plans. 
While the first two scenarios are stable end points, the chaos scenario is a disequilibrium state somewhere between today's system and a future competitive system. If possible, this scenario is to be avoided. If the industry finds itself in this situation, it will try to leave it as quickly as possible. This scenario has alternative outcomes, each of which reflects society's inability to overcome various technological, economic, or institutional barriers that prevent completion of the transition from today's industry structure to either the wholesale- or retailcompetition scenario. Given the complexities and uncertainties of this scenario, it is difficult to identify a clear role for IRP.

The workshop participants identified many needs for additional research and policy analysis. Most of these issues covered more than one scenario. They fell naturally into 13 categories, including generation, transmission, distribution, system, societal, regulatory, environmental, legal, transitional, IRP, demand-side management, externality, and data and analytical-tools issues. Key topics include:

- utility divestiture of generation, control-center, and/or transmission assets and functions;

- estimation and allocation of the costs associated with stranded commitments (primarily expensive power plants and purchase-power contracts);

- ownership and operation of the control center and of the transmission network and the relationship between these two entities;

- the roles of utilities, government, and others in delivering energy-efficiency services to customers and in acquiring renewable energy resources; and

- the roles of various organizations and government agencies in resource planning, including public participation. 


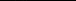




\section{LIST OF ACRONYMS}

DISCO Distribution-only utility

DSM

Demand-side management

FERC

Federal Energy Regulatory Commission

GENCO

Generation-only company

IPP

Independent power producer

IRP

Integrated resource planning

PBR

Performance-based regulation

POOLCO

Entity responsible for dispatch and control of power plants

PUC

Public utility commission

R\&D

Research and development

RFP

Request for proposals

RTG

Regional transmission group

$T \& D$

Transmission and distribution

TRANSCO

Transmission-only company 


\section{INTRODUCTION}

The electric-power industry is experiencing dramatic change, primarily because of increased competition at both the wholesale and retail levels. The vertically integrated utility industry of today is undergoing a major transition that could lead to an industry characterized by a host of independent power producers (IPPs) and others that own power plants (GENCOs), whose output is dispatched and controlled by power pools (POOLCOs), transported by independently owned transmission systems (TRANSCOs), and marketed by distribution utilities (DISCOs) that are divested of their generation and transmission assets and that distribute power to core customers. Other views of the future of the industry are equally logical and compelling.

These changes are motivated by several factors. Prior efforts to deregulate and promote competition in other industries (e.g., banking, telecommunications, trucking, airlines, and natural gas) suggest that such structural changes can improve economic efficiency and increase customer choices. Within the electricity industry, many participants are frustrated by average-cost pricing (which sends economically inefficient price signals to customers), the complexities and delays associated with state and federal regulatory processes, and the associated allocation of many risks to customers (rather than, say, to utility shareholders).

On the other hand, the current system of vertically integrated utilities performs many important functions. These functions include resource-portfolio management on behalf of customers (selection of a range of technologies and fuels with which to produce electricity), cooperation among utilities to provide system-reliability services, support for energy research and development, provision of demand-side management (DSM) programs, and acquisition of renewable resources.

Questions abound concerning the future of the utility industry. Will competition increase economic efficiency, and if so, by how much? Are most of these gains likely to occur at the wholesale level or at the retail level? Is retail wheeling necessary, desirable, or inevitable? How important are stranded commitments and the allocation of these costs? How will environmental goals (e.g., stricter controls on $\mathrm{NO}_{\mathrm{x}}$ and $\mathrm{CO}_{2}$ ) and other societal programs currently being accomplished by utilities be met in the future? How will system reliability be ensured? How will regulation of the new industry be allocated between the federal and state governments [i.e., between the Federal Energy Regulation Commission (FERC) and state public utility commissions (PUCs)]? 
Other important questions are being raised about the role of integrated resource planning (IRP) for the future electric-power industry. Will competition lessen the need for IRP or eliminate it altogether? Does IRP facilitate or inhibit competition? How might IRP change to meet future regulatory and societal needs? Who would prepare and review IRPs? What aspects of IRP support a transition to competition? Will the long-run economic focus of IRP survive in the future industry even if IRP does not? Closely related to IRP are additional questions about DSM and renewable resources. In particular, will DSM and renewables continue to be acquired in the new competitive world, or will the new industry have few incentives to fund such efforts as DSM programs and renewable setasides?

The answers to these questions are complex and depend heavily on one's view of the future electricity industry. To help tackle these questions in a systematic fashion, Oak Ridge National Laboratory (with funding from the U.S. Department of Energy) sponsored a Workshop on IRP and the Electricity Industry of the Future, July 19-20, 1994, in Chicago, Illinois.

We invited the 30 workshop participants for their significant contributions to and understanding of IRP and to represent important stakeholder views. Specifically, we drew participants from utilities, PUCs, interest organizations, the research community, and DOE and its national laboratories. Appendix A lists the workshop participants, and Appendix B contains the workshop agenda.

The goals of the workshop were to:

- Discuss and refine three alternative scenarios for the electricity industry.

- Examine the needs for planning, including IRP, in the electricity industry of the future depicted in each scenario.

- Identify research and analysis topics that could be pursued to improve planning and assist the industry in its transition to the future.

To achieve these goals, we developed a methodology, discussed in Chapter 2, centered around focused discussion of three scenarios for the electric industry of the future. We divided the participants into three groups, each tasked with considering a specific scenario. Chapters 3 through 5 describe the scenarios and summarize each group's discussions.

Chapter 6 synthesizes the research questions that arose during the discussions. The questions cover a wide array of topics, including industry structure (ownership and operation), legalities, environmental quality, transition planning, and, of course, IRP 


\section{WORKSHOP METHODOLOGY}

The workshop focused on three scenarios that depict alternative futures of the electricity industry. The first scenario depicts an industry characterized by widespread wholesale competition. This scenario is the closest of the three to today's industry. The second scenario envisions an industry that includes both wholesale and retail competition. This scenario is similar to the one envisioned by the California PUC in its April 1994 proposal. The third scenario pictures an industry beset by chaos. This scenario could be interpreted as a transitional stage between the first two scenarios or as a situation that evolves after attempts to reach the second scenario fail. For the most part, participants viewed the first two scenarios (wholesale competition and retail competition) as potentially steady-state situations. Participants considered the third scenario (chaos) an unstable situation that needs to be avoided at all costs

We sent participants one-page descriptions of the three scenarios before the workshop. During the afternoon of the first day, we met in a plenary session to discuss each scenario. Then we assigned each participant to one of the three scenarios. Each group discussed, clarified, and refined its scenario, broadly keeping with the original theme of the scenario. Chapters 3 through 5 describe each scenario (Table 1).

Once consensus had been reached on the particulars of each scenario, the groups addressed six questions that we had distributed before the workshop. The groups reported back in plenary session the results of their discussions. Chapters 3 through 5 contain the responses to Questions 1 through 4 and Chapter 6 contains the responses to Questions 5 and 6 . The questions are:

1. What factors in your scenario necessitate an electric-industry planning function to ensure the provision of adequate, reliable service at the lowest reasonable costs with due consideration given to the environment, public health, and other important societal issues?

2. What factors in your scenario reduce the need for an electric-industry planning function?

3. What factors in your scenario constrain the implementation of an electric-industry planning function?

4. Given insights arising from discussions on the first three questions, what characteristics might an electric-industry planning function have in your scenario, if any? 
Wholesale

competition
Retail

competition
Transitional

chaos

\section{Generation \\ Ownership \\ IPPs and utilities GENCOs \\ IPPs and utilities \\ Resource mix \\ Natural gas gains \\ Natural gas gains \\ Little change \\ Dispatch \\ Utility control \\ POOLCOs \\ Utility control \\ centers centers and POOLCOS}

\begin{tabular}{ccll}
$\begin{array}{c}\text { Transmission } \\
\text { Ownership }\end{array}$ & Utilities & TRANSCOs & $\begin{array}{l}\text { Utilities and } \\
\text { TRANSCOs }\end{array}$ \\
Reliability & High & $\begin{array}{l}\text { Potential } \\
\text { problems }\end{array}$ & Unreliable \\
\hline
\end{tabular}

Distribution

Ownership

Utilities

DISCOs

Utilities and DISCOs

Retail wheeling

Limited

Commonplace

In limbo

\section{Regulation \\ Major issues \\ Performance- \\ based regulation \\ Stranded \\ investment \\ Improving IRP}

$\begin{array}{ll}\text { Divestiture } & \text { Stranded } \\ \text { Transmission } & \text { investment } \\ \text { planning } & \text { Intergovern- } \\ \text { Social obligations } & \text { mental conflicts } \\ & \text { Transmission } \\ & \text { access }\end{array}$

Divestiture

Stranded

investment Intergovernmental conflicts access 
5. What research activities should be undertaken to resolve uncertainties about your planning-function proposals?

6. What other research activities could be undertaken to assist the electric industry and its regulators make the transition to the electric industry of the future?

Question 1 broadly encompasses any type of planning that is either government or privatesector initiated and implemented and that is subsequently executed to achieve the above stated goals. The question is broad because IRP, one of many possible approaches to electric-industry planning, could be rejected for various reasons even though some type of planning might still be required. On the other hand, IRP might remain a strong and viable process that must be retained. As a third option, IRP might evolve into new forms under the same name. Thus, in many instances in this report, the term "IRP" depicts a resource-planning process that is different from IRP of today.

Many factors about the electric-utility industry and its regulation during the 1980s led to IRP (e.g., excess capacity, expensive nuclear plants, air pollution from power plants, and utility inattention to energy-efficiency and renewable-resource options). Question 2 probes whether such factors would exist in the future. In addition, Question 3 highlights that numerous practical issues plague even the most beneficial, universally agreed-upon ideas. For example, the amount of time needed to prepare, review, revise, and approve IRP plans is a major problem.

The groups used insights gained in discussing the first three questions to answer the fourth, which pertains to suggestions for planning functions for the electricity industry. We prepared a worksheet that listed specific questions about planning in general and IRP in particular (e.g., Does this planning function include a load forecast? If so, who prepares it? How is the public involved? What is the planning horizon? Are the plans formally reviewed? By whom?). Each group was encouraged to provide caveats to their suggestions and to make clear any important assumptions.

Questions 5 and 6 help create a research and analysis agenda on IRP and industry transition. Research and analysis activities include concept development, data collection and analysis, experimentation, and policy analysis. One example activity might be to develop suggestions for streamlining IRP to reduce the amount of time and cost to complete a resource plan. Another might be to identify the magnitude of "stranded investment" and the stakeholders that are most financially at risk.

In addition to the three scenarios and the six questions, we sent participants a list of ten wildcards that could affect these scenarios. We asked the groups to consider these wildcards in their deliberations. The wildcards included: global warming and ozone depletion are confirmed; stricter air and waste regulations are promulgated; the electric power industry experiences unprecedented consolidation; interest rates skyrocket; public cynicism toward the industry 
becomes rampant; social unrest is widespread; the information highway is successfully constructed; major breakthroughs are made in transmission and generation technologies; electricity demand increases unexpectedly; and democracy in Russia fails. In general, the groups did not have time to address the wildcards but wish they had.

Finally, this report cannot fully express the diversity of opinions held by the workshop participants. Also, in many instances, topics that we initially thought were simple to understand turned out to be quite intellectually challenging. Few topics that we originally thought to be challenging ended up being simple! As a result, there was often a "messiness" to the workshop process, as one participant put it. Out of the milieu came the ideas, suggestions, and insights presented herein. 


\section{WHOLESALE-COMPETITION SCENARIO}

\section{SCENARIO DESCRIPTION}

This scenario is characterized by electric utilities that remain vertically integrated with a retail monopoly franchise (Fig. 1). The typical utility would own generation, transmission, and distribution facilities; operate power plants from its control center or as part of a larger utilityowned power pool; and maintain an exclusive franchise to sell electricity to retail customers located in its geographic service area. In addition to utility generation, IPPs would sell capacity and energy to the local utility under long-term contracts and might also sell electricity on the spot market through the power pool. Although retail wheeling is not permitted in this scenario, the pressure for such transactions would affect the utility and its ongoing efforts to cut costs. Pressure would also exist to require utilities to divest themselves of their generation and transmission assets as well as their control-center functions to ensure that wholesale competition works well.

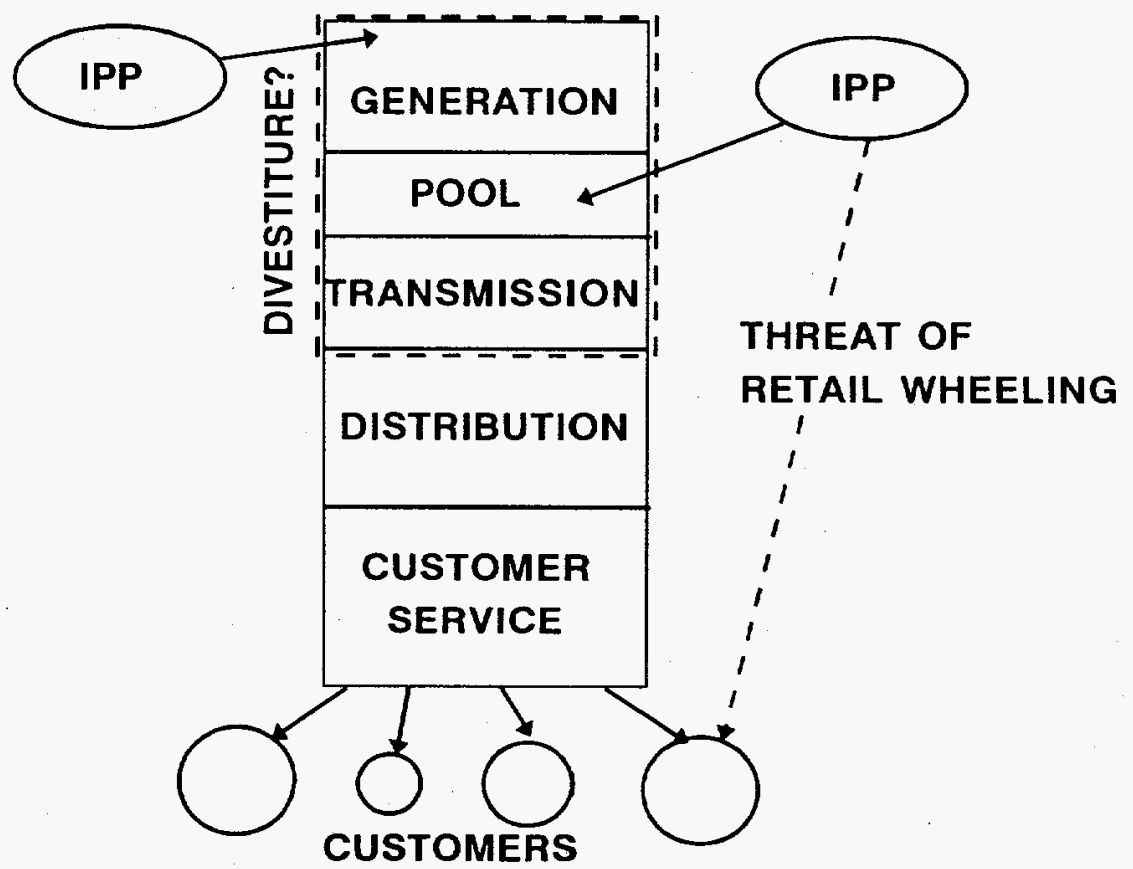

Fig. 1. Structure of electricity industry in which wholesale (but not retail) competition occurs. Dotted lines represent potential changes from this scenario, in particular possible utility divestiture of its generation and transmission assets and its control-center functions. 
The utility of the future in this scenario would differ from today's typical situation in three respects. First, IPPs would account for almost half of the utility's power supply, primarily through contracts and secondarily through spot purchases. Second, retail wheeling would be a real possibility. (In many locations, this scenario is today's reality.) The costs of uneconomic utility generating plant (i.e., what would otherwise be considered stranded investment) would not be a critical issue because, absent retail wheeling, these costs could be shared among all customer classes and utility shareholders. Third, concern about retail competition (assumed to be based primarily on prices rather than costs) would reduce the scope of utility DSM programs. These programs would be considered less of a resource (in terms of providing energy and capacity) and more of a customer service.

IPPs would build new power plants primarily in response to requests for proposals (RFPs) issued by utilities. Utilities would add to their generating assets only when it is clearly cost effective to do so (e.g., repowering existing utility-owned plants). IPPs would be free to build power plants, the output of which they might sell into the pool at spot prices. Such speculative building is not envisioned as long as utilities (perhaps in response to PUC requirements) conduct auctions that lead to the signing of long-term contracts (although long-term might be 5 to 10 years, rather than $20+$ years).

Utilities in this scenario would operate with performance-based regulation (PBR). This "light" regulation would provide them substantial flexibility to offer various pricing options to their customers and reduce the frequency and complexity of traditional rate cases. Although the details of PBR were not discussed (in particular, price vs revenue caps), rate regulation might be simpler than it has been in the past. New PUC regulations, combined with competitive pressures, might impose cost-cutting pressures on utilities. In response to PBR, as well as to the continuing threat of retail competition, utilities would likely offer their customers much greater choices in pricing, including real-time pricing, and unbundling and separate pricing of various services (e.g., reliability). PUCs could structure PBRs to ensure that utility shareholders are indifferent to utility vs IPP generation resources. However, PUCs may find it difficult to oversee PBR to ensure that utilities do not unduly discriminate among customer classes.

This scenario could be sustainable (i.e., a steady-state situation). If IPPs and utilities compete fairly with each other to supply generation to the wholesale market at competitive prices with open access to transmission services and if utilities use the flexibility provided by PBR, then pressures to change from this scenario could be modest. (Several workshop participants disagreed with this statement and felt that retail wheeling was inevitable, desirable, or both.) Such open access implies that transmission planning, access, pricing, and operation might be much more important than they have been in the past. If, however, utilities abuse their monopoly power over their transmission networks and power-pooling functions, then two sets of strong pressures could emerge. The first set would call for utility divestiture of generation and perhaps of generation, transmission, and power pooling (dispatch and control). The second set of pressures would call for direct access, to allow retail customers to select their suppliers. 


\section{PLANNING AND RESEARCH ISSUES}

Question 1. What factors in your scenario necessitate an electric-industry planning function?

- Ensure that the utility meets its obligation to serve adequately and fairly its retail customers.

- Provide least-cost energy services to retail customers (balancing demand and supply resources).

- Ensure that planning and expansion of the transmission and distribution (T\&D) system are consistent with supply planning and needs as well as with customer interests.

- Protect against monopoly abuse caused by utility ownership and management of control centers and transmission networks.

- Maintain reliability (although pricing innovations may reduce the importance of traditional reliability concepts).

- Ensure environmental protection.

- Maintain retail rate stability.

- Allow for public participation.

These goals are much the same as those that exist today and that are satisfied through IRP.

Question 2. What factors in your scenario reduce the need for an electric-industry planning function?

If IPPs perform well (i.e., build and operate power plants at low cost and high reliability), utilities will have more flexibility to acquire energy and capacity resources quickly and easily.

Question 3. What factors in your scenario constrain the implementation of an electric-industry planning function?

- Future bypass (retail wheeling) may be encouraged if IRP leads to decisions inconsistent with what customers want and are willing to pay for.

- The size and vigor of the IPP market may obviate the need for IRP if a functioning competitive wholesale market accomplishes much of what IRP otherwise would.

- Utilities may be reluctant to share information that would hurt their competitive positions. 
- Pressures to reduce utility costs (e.g., concern about retail wheeling) may cause utilities and their regulators to ignore broad societal concerns, such as environmental quality.

Question 4. Given insights arising from discussions on the first three questions, what characteristics might an electric-industry planning function have in your scenario, if any?

Utility-based IRP would still dominate as the planning approach in this scenario. Many elements of IRP would be much the same as they are today. However, IRP could also change in several significant ways.

IRPs would continue to include load forecasts. Forecasting in this scenario is more difficult and uncertain than it is today because utilities would be concerned about the possible loss of retail customers. Perhaps utilities would focus more on low load forecasts and less on the medium and high forecasts. Utility forecasting and planning may focus more on the use of realtime pricing to manage rapid load growth and to reduce the need to acquire peaking capacity.

Utilities would continue to assess their existing resources, which include contracts to purchase power as well as utility-owned plants. Utilities would continue to produce fuel-price forecasts, primarily for use in structuring RFPs and IPP contracts. Utilities would also continue to plan to meet the T\&D needs of all customers in their service areas.

One difference between IRP today and IRP as envisioned in this scenario is that utilities would shorten their planning horizons and focus more on their short-term action plans. The threat of retail wheeling and municipalization would be a major driver. In addition, utilities would generally not be building their own 40-year-lifetime power plants, but instead would be signing 5- to 10-year contracts to purchase power from others.

Transmission planning would be increasingly important and better integrated into IRP. The greater importance of transmission planning would stem from the growing use of nonutility (IPP) sources of power and the need to ensure comparable access to transmission services. State and federal regulators would scrutinize transmission planning and operation more closely to be sure that utilities would not use these monopoly assets to their own advantage (relative to IPPs). Also, because utilities generally would not build new power plants, T\&D investments would be a much larger share of utility capital budgets than was true in the past.

IRP would involve greater coordination within the utility among various departments, including supply planning, T\&D planning, pricing, and customer service. This greater coordination would be required by increased emphasis on planning and operating the utility's T\&D system to support a much greater number of transactions involving more suppliers than exist today. In addition, more departments within the utility would be involved in IRP because of the tensions between planning to minimize cost and planning to maximize customer value. 
Pricing would be a more important part of resource planning, both because of the effects that pricing structures can have on the need for new supplies and because of growing concerns about interclass subsidies. Thus, long-run marginal costs would be used more fully and explicitly in the design of rate structures. Utility cost-of-service studies would grow in importance, be coordinated with resource planning, and include spatial details (to reflect differences in locational $T \& D$ costs). Increasingly, utilities would seek to shift fixed costs from the volumetric elements of retail tariffs (the charges per $\mathrm{kW}$ and per $\mathrm{kWh}$ ) to the monthly customer charge.

Ensuring fair access to control-center and transmission services would lead to greater unbundling of these services. Such services as regulating margin, spinning reserve, and frequency control, which previously were all bundled into the overall price of electricity, may now be separately costed and priced.

Also, the increase in pricing options (especially those that add a real-time component to customer prices) would reduce the emphasis on today's concepts of reliability. In other words, short-term (hour-to-hour) variations in electricity prices may (depending on price elasticities) reduce the need to maintain generation and transmission reserve margins, a partial substitution of economics for engineering. Of course, these changes rely on the existence of a competitive wholesale power market and the efficient operation of a power pool.

As part of their resource planning and RFP preparation, utilities would consider how best to share risks with IPPs. Utilities would be more concerned about risks because of their worries that greater retail competition would reduce the loads they must meet.

Utility IRP reports would continue to be submitted to PUCs. However, these reports would likely be simpler, shorter, and less detailed than today's typical IRP report. This simplification would arise in part because, with utilities less likely to build power plants, the costs of new generation would be determined primarily by markets rather than by utility analysis. Thus, the reports would contain less information on specific resources to be acquired and more information on resource needs and on how resources would be acquired through contract mechanisms.

The reports may contain less data that could be useful to a utility's competitors (although utilities might be concerned about the adverse publicity caused by withholding information from some parties). Utilities might not include marginal-cost estimates in their resource plans, counting on competitive auctions to let the market provide such information. PUCs would continue, under confidentiality agreements, to obtain access to the utility's detailed cost data.

Overall, IRPs would serve primarily as corporate-strategic-policy documents. PUC responses - acknowledgment, acceptance, or approval-would be diverse, as is true today. PUCs would be unlikely to approve individual resource acquisitions and would instead approve overall resource strategies, including RFPs. PUCs are unlikely to want to approve individual contracts, in part because the costs of these contracts will be automatically covered by PBR. 
Public participation in a utility's preparation of its resource plan would continue in this scenario. PUCs may grant utilities greater discretion on who can (must) participate in such processes. For example, utilities may be able to exclude competitors, such as IPPs and the local gas companies, because these entities have other opportunities to express their views (e.g., by preparing bids in response to utility RFPs and by competing for retail load, respectively).

Incorporating societal concerns into resource planning (e.g., environmental externalities and the acquisition of near-cost-effective renewables) would be more difficult if these actions increase electricity prices and make utilities less competitive. On the other hand, PUCs may find ways (e.g., by taxing use of the T\&D system) to impose the same types of costs on nonutility suppliers. More generally, PUCs would struggle to impose consistent obligations on all power suppliers.

On the other hand, there may be fewer regulatory conflicts involving IRPs if utilities primarily purchase power through contracts rather than build their own power plants. This simplification would arise in part because buy decisions can be implemented more quickly than can build decisions. This shorter lead time would permit utilities and PUCs to defer some decisions that in the past had to be made several years in advance of need. This reduction in implementation time may reduce uncertainty in utility planning. However, negotiating detailed contract terms and conditions (especially the assignment of different risks to the utility vs the supplier) may be complicated and time consuming. Also, to the extent that IPPs build plants for the spot market (i.e., to sell directly into the pool), utilities have to do less supply planning than in the past. However, if utilities continue to build power plants, the role of regulators would increase to ensure that utilities do not favor their own projects at the expense of IPP projects.

Commissions would use IRPs to help ensure that IPPs can compete fairly with utilities (i.e., to coordinate market forces with regulation). The preferred mechanism to ensure access for IPPs would be utility RFPs to acquire new resources. Although utilities may choose not to publish avoided-cost details in their RFPs, they would specify the amounts of energy and capacity, timing (when), and types (baseload, intermediate, or peaking) of capacity and energy they need.

PBR would affect IRP, but how is not clear. PBR might remove the biases in current state regulation (1) to build rather than buy generating resources and (2) to promote load growth rather than customer energy efficiency. PBR would also allow utilities to rapidly respond to retail markets by offering competitive pricing options to their customers. Finally, PBR would reduce the need for regulators to review all the details of utility resource acquisitions and operations, perhaps reducing the need to prepare detailed IRPs for public consumption.

Similarly, creation of regional transmission groups (RTGs) might affect IRP, but how is not clear. It is possible that RTGs would assume some responsibility for resource, not just transmission, planning on a regional scale. 


\section{RETAIL-COMPETITION SCENARIO}

\section{SCENARIO DESCRIPTION}

This scenario is characterized by wholesale competition (an expanded version of that described above) plus widespread retail competition (Fig. 2). Investor-owned utilities would have divested themselves of their generation and transmission assets. In this scenario, they would become distribution-only companies (DISCOs). Publicly owned utilities (rural electric coops and municipalities) would also be DISCOs under this scenario. DISCOs would have an obligation to buy power for, and sell power to, their core customers (residential, small commercial, and some industrial customers). While customers would be free to seek service elsewhere and alternative suppliers would be free to market their products and services, high transaction costs might often make such deals uneconomical for small customers. Thus, DISCOs would retain near-monopoly franchises in their service areas with respect to most small and medium-size customers.

Because of their de facto monopolies over service for smaller customers and clear monopoly over the local distribution system, DISCOs would still be regulated by PUCs. PUCs would continue to try to require that DISCOs fund certain social programs, such as special services for low-income households, and DSM programs. DISCOs would argue that the programs cost too much and would be spread over too small a customer base. Some DISCOs would be forced to raise retail rates, rendering them less competitive with other suppliers (who, presumably, are not required to offer these services). Society would need to consider alternative ways of supporting these programs (e.g., government programs supported by taxes or privatepublic partnerships).

Generation-only companies (GENCOs, which include IPPs as well as companies that were formerly part of vertically integrated utilities) would build and operate power plants. These companies would not be regulated by PUCs. FERC, in response to the exempt wholesale generator part of the Energy Policy Act of 1992, would also not regulate these companies. However, federal and state environmental laws would affect the siting and operation of generation facilities. In certain cases, state agencies responsible for enforcing these laws may also regulate fuel choice to meet air-quality requirements. 


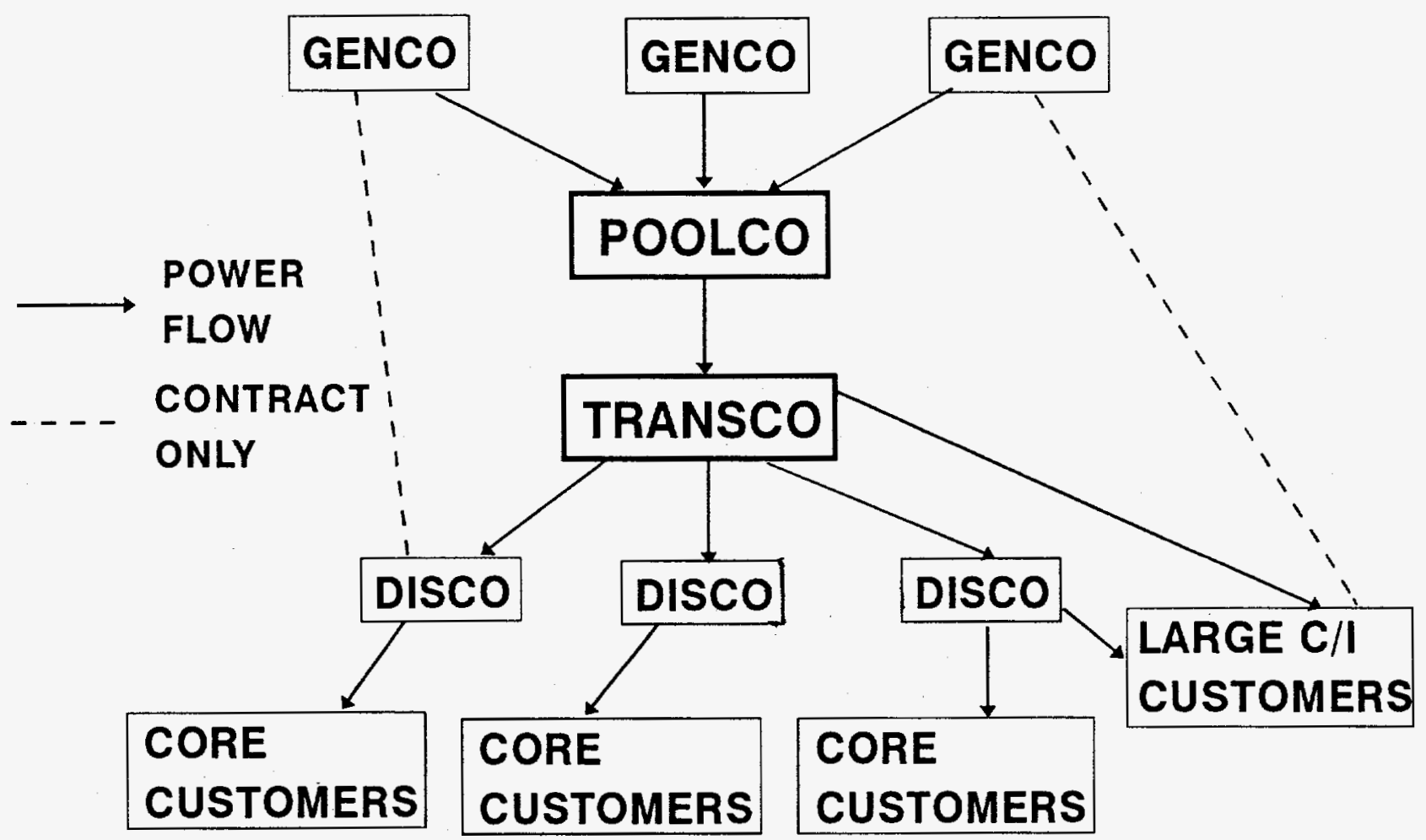

Fig. 2.

Structure of electricity industry in which wholesale and retail competition occurs. Regulators might impose barriers between GENCOs and the POOLCO and between the POOLCO and the TRANSCO to prevent anticompetitive behavior. ( $\mathrm{C} / \mathrm{I}$ refers to commercial and industrial customers.)

Independent entities known as TRANSCOs would take over construction, technical operation (e.g., maintaining system integrity as opposed to making power-dispatch decisions), and maintenance of the transmission system to ensure that all producers and buyers have fair and equal access to the system. TRANSCOs might be owned by the private sector or the government. FERC would continue to regulate the transmission component of the industry to ensure open access and fair pricing of these monopoly transmission services. Reliability councils would continue to operate independent of government intervention to ensure transmission-grid reliability. It is unclear whether and how the reliability councils would ensure adequate generating reserves. Alternatively, the reliability-council functions could be folded into RTGs, which might be responsible for transmission planning, pricing, and reliability.

The marketing and purchasing of power would be distinct from the dispatch of power plants; that is, the flows of money and electrons might be largely independent. With respect to dispatch and control, power pools would (much as today's utility control centers and "tight" power pools do) schedule and dispatch power plants to provide least-cost electricity while maintaining system stability. POOLCOs would be established as separate entities whose sole 
purpose would be to dispatch and control GENCO power plants to ensure that DISCO and largeindustrial-customer demands are met at the lowest cost. Thus, POOLCOs would act between GENCOs and buyers to dispatch power plants, maintain system stability and reliability, establish market clearing prices (based on short-run marginal costs), collect revenues from buyers, and distribute revenues to sellers. POOLCOs would own no generation or transmission assets and would exist solely to ensure the least-cost production of electricity to meet the time-varying demands of customers. The most efficient structure would probably involve POOLCOs and multilateral agreements among GENCOs and DISCOs and large retail customers, although informal power pools and numerous bilateral agreements would be possible.

GENCOs could sign contracts with DISCOs and large industrial customers or sell to the power pool, which would then enter into agreements with DISCOs, individually or in aggregate (i.e., through multilateral agreements). GENCOs would have contractual agreements to supply power to the seller or the pool. Within those agreements, GENCOs could produce the power themselves or buy the power from other GENCOs (e.g., if the GENCO has a forced outage) to meet their obligations.

Large nongenerating industrial customers could buy power directly from the pools or from their local DISCO. Large cogenerating industrials would probably supply excess power to the pool and also contract with the pool or other suppliers to buy power when needed.

Retail wheeling, therefore, could be common as contractual obligations to provide power become separated from the historical utility service areas. The majority of customers that purchase small amounts of electricity may not find it worthwhile to pursue retail wheeling. Transaction costs would be large, and savings would be minimal. However, some customers might switch suppliers just for the sake of change. However, in the long-run, DISCOs would continue to serve the majority of customers in their service territories. Therefore, DISCOs might retain de facto monopoly control over their service territories.

To minimize conflicts of interest and gamesmanship, "firewalls" could be built between the GENCOs, POOLCOs, TRANSCOs, and DISCOs. That is, GENCOs would not be allowed to own transmission or distribution assets, TRANSCOs would not be allowed to own generation or distribution assets, and DISCOs would not be allowed to own generation or transmission assets. How this situation might evolve, especially how uneconomical generation assets could be equitably divested, are serious and unresolved questions. How large industrial cuștomers might uncouple from DISCO service is also unclear. In a fully operational retail competitive market, large industrial consumers could sign contracts with DISCOs or join multilateral agreements with the POOLCO.

Buyers and sellers would be assessed a transmission fee (probably through the POOLCO) by the TRANSCOs to fund the operation and maintenance (and perhaps construction) of transmission systems. FERC would oversee the setting of the fees. However, it is unclear how 
the fees would be developed and the extent to which transmission services would be unbundled and separately priced.

Energy-service companies would also be able to sell energy and demand savings to DISCOS and to individual customers. DSM and renewables could still be supported through various taxes and requirements placed on DISCO acquisition of electricity resources through the POOLCO. DISCOs might acquire these resources in any case if they are economically competitive.

Public participation in electric-industry decisions would need to be more creative and diverse. Issues dealing with DSM and renewables must be brought to PUCs and DISCOs. TRANSCOs, as well as the associated POOLCOs and GENCOs must address electromagneticfield concerns. Siting concerns must be raised with prospective GENCOs and the proper regulatory bodies.

\section{PLANNING AND RESEARCH ISSUES}

\section{Question 1. What factors in your scenario necessitate an electric-industry planning function?}

- Ensure that owners and regulators of the transmission system do not abuse their monopoly power (e.g., by setting fees too high or too low) and that they efficiently plan the transmission system.

- Ensure that DISCOs do not abuse their virtual monopoly power (e.g., by adding questionable fees to distribution services or by discriminating against certain customers) and that they efficiently plan the distribution system.

- Protect against the abuse of monopoly power in wholesale markets.

- Ensure that environmental goals are met (e.g., air quality, electromagnetic fields, and local power-plant siting concerns).

- Maintain price stability for residential and small commercial and industrial customers.

- Promote fuel diversity.

- Balance equity versus efficiency in satisfying societal goals.

- Manage load-shedding priorities in times of system crisis to protect public health, safety, and welfare 
Question 2. What factors in your scenario reduce the need for an electric-industry planning function?

The most important factor is the belief that competitive markets are more likely to provide ample and cheap supplies of electricity than is regulation. Thus, markets would eliminate the need for government regulated planning, but private firms would continue to plan and conduct market research. For example, in response to Question 1, we listed fuel diversity as a factor that requires planning. However, retail customers, either acting on their own or through their selection of supplier, could choose the amount of diversity they want without government involvement.

Several assumptions underlie the belief in competitive markets. For example, one must assume that power pools would function as expected (i.e., balancing the supply of and demand for electricity at competitive prices). To allow the spot market to operate efficiently, one must assume that sellers and buyers are sophisticated enough to set and respond to real-time prices and that they possess the technical wherewithal to operate in this market. One must also assume that the law of large numbers applies in the generation sector (e.g., that POOLCOs can draw upon many suppliers to meet demand when plants unexpectedly go offline).

Lastly, one must assume that pricing incentives keep the market fair and responsive. Under different POOLCO operating and pricing rules, buyers and sellers might not reveal their true selling and purchase prices, allowing one or the other to extract rents that would reduce the overall efficiency of the market. Large concentrations of generating assets or strategic use of transmission constraints make this a real possibility:

Question 3. What factors in your scenario constrain the implementation of an electric-industry planning function?

Numerous factors could constrain planning within this scenario. One factor is regulatory. Who has authority over what? For example, the federal government lacks authority to regulate the siting of new transmission facilities, although it has other authorities over transmission (e.g., access and pricing provisions). The states may lack authority to set and collect transmission fees to pay for societal programs; such authority may reside with FERC. If government transmission planning were warranted or needed, these types of jurisdictional questions would need to be addressed.

A major feature of this scenario is concern about whether social programs should continue to be provided by the electricity industry. One problem constraining the provision of such services (e.g., low-income retrofit, DSM, renewables, and energy research and development) is the nature of the functions themselves. By moving to retail competition, society might (implicitly, at least) accept the notion that the electric industry must no longer meet certain societal obligations. One might assume that a competitive market can better meet these societal needs (e.g., acquisition of 
appropriate amounts of energy-efficiency and renewable resources) than can regulation. If this is not the case and obligations remain, what are these obligations, and who should provide them?

The decentralized nature of the industry in this scenario could make it difficult to plan comprehensively. That is, making trade-offs among stakeholders in a decentralized system to maximize social welfare would be difficult because some participants might be less well off. The competitive nature of the industry would also make it difficult to collect and share the information necessary for integrated planning.

At the state level, existing environmental laws (e.g., rules on air quality and hazardous waste disposal) could best be met through a coordinated effort to plan the siting of new generation plants and the fuels to be used by the plants. However, such planning would be difficult because PUCs would not have jurisdiction over the GENCOs, which would leave such planning oversight to state environmental offices. (Some believe that this would be a desirable change, arguing that PUCs have no competence in environmental issues and that such matters should be left to environmental agencies.)

Question 4. Given insights arising from discussions on the first three questions, what characteristics might an electric-industry planning function have in your scenario, if any?

Unlike the wholesale-generation scenario, where IRP would still be the main planning vehicle, this scenario would be characterized by at least five different planning functions.

- Distribution-system planning: IRP would be different from today in that details about purchase-power contracts would replace details concerning the construction of specific power plants. DSM may or may not be pursued as a resource, depending on PUC requirements and the costs and benefits of DSM as perceived by the DISCO. Load forecasts would be more uncertain because utilities would not know which customers they would be serving in the future. Therefore, forecasting and planning would entail a shorter planning horizon. Also, forecasting may become more like market research-trying to understand and predict the response of customers to different pricing and service options - with less focus on predicting total system load. The public would still be involved in the development of these plans, but contention might be reduced because the more troublesome environmental and health issues would be debated in other forums. A difficult set of distribution-planning issues concerns the unbundling and separate pricing of key distribution services (e.g., loss management, outage restoration, network monitoring and control, and adjustment for reactive power).

Transmission-system planning: Load forecasts are also needed to assist in setting prices and building new infrastructure. The public would be active in its comments on the siting of new transmission lines because of concerns about electromagnetic fields, with opposition increasing as justifications for new lines are based solely on economic 
arguments, many of which would benefit out-of-state interests. Perhaps, planning should be done for the entire North American continent, but who could do it is unclear. Both monetary and nonmonetary costs need to be factored into transmission planning. The same unbundling and pricing issues that occur in distribution (noted above) occur for transmission also.

- System-reliability planning: The electric-reliability councils, as currently institutionalized, may not exist in this scenario. The traditional cooperation among vertically integrated utilities would not withstand competitive pressures among owners of generation assets to ensure that as much power as they have available is sold on demand. The RTGs might take over the responsibility for reliability planning, but participants were skeptical that RTGs would be able to do so. No clear suggestions were made about how to plan for appropriate levels of reliability. Real-time pricing may reduce the importance of reliability planning, although GENCOs, the POOLCO, and the TRANSCO would still have to cooperate on a second-to-second basis to ensure system stability.

- Environmental and siting planning: Some kind of statewide planning would be necessary to site new plants because coordination is needed to meet clean-air and other environmental goals. The public would be involved in these decisions. To avoid having site by site, hit and miss regulation, states would need to develop general guidelines for power-plant siting.

- Generation planning: Because of increased competition, GENCOs may feel constrained to plan for periods of only a few years. On the other hand, it will still take several years to plan, design, and build a power plant, which indicates that GENCOs would use longer planning horizons. Forward contracting or options markets might help overcome this problem. Lastly, the government would not be closely involved in generation planning; rather, the key decisions would be left to the competitive marketplace. However, GENCOs would need to deal with environmental regulations and guidelines.

The integrated part of IRP is likely to largely disappear in this scenario. Even though all the traditional elements of resource planning remain, they are conducted by disparate entities that have little incentive to cooperate and coordinate with each other. To the extent that there is a need for integrated resource planning, government agencies (e.g., PUCs or state energy offices) may develop such plans. These state plans could then form the broad structure within which GENCOs, TRANSCOs, and DISCOs would plan their futures. 



\section{CHAOS SCENARIO}

\section{SCENARIO DESCRIPTION}

The chaos scenario is a disequilibrium state somewhere between competition and regulation. Unlike the two preceding scenarios, which could be stable endpoints, this is an unstable state. If possible, this scenario is one to be avoided. If the industry is in this scenario, efforts would focus on leaving it as quickly as possible. The potential adverse consequences of this scenario are so negative that a regulated, orderly, but possibly economically inefficient transition could be better than continued chaos.

As shown in Fig. 3, this situation is fractured between the industry as it is today (on the left) and the industry posited in the retail-competition scenario (on the right). Today, vertically integrated utilities own generation, transmission, and distribution assets and serve captive retail customers. The future could be characterized by separate GENCOs, TRANSCOs, and DISCOs and by the ability of retail customers to contract directly for power (retail wheeling). As discussed below, this scenario is really a series of alternative outcomes, all of them undesirable. These paths reflect society's inability to make the transition from today's industry structure and its regulation to some future stable situation.

Chaos could occur because of the partial existence of both situations (e.g., some states retain an integrated industry while others move toward retail competition, or some states find themselves with aspects of both situations) and because expectations of continued transition are not being met.

Efforts to develop competitive electricity markets might fail for a variety of technological, economic, or institutional reasons. Technological failures might involve proof of global warming, which would severely limit operation of coal plants; premature retirement of nuclear plants caused by the high costs of continued operation; or increased outages caused by reduced operations and maintenance budgets at power plants. Economic failures might involve dominance of wholesale markets by a few suppliers or utility ability to "game" performance-based regulation. Institutional failures might involve overlapping and confusing federal/state regulations, an uncomfortable mix of regulation and markets, or widely disparate systems in neighboring states. 

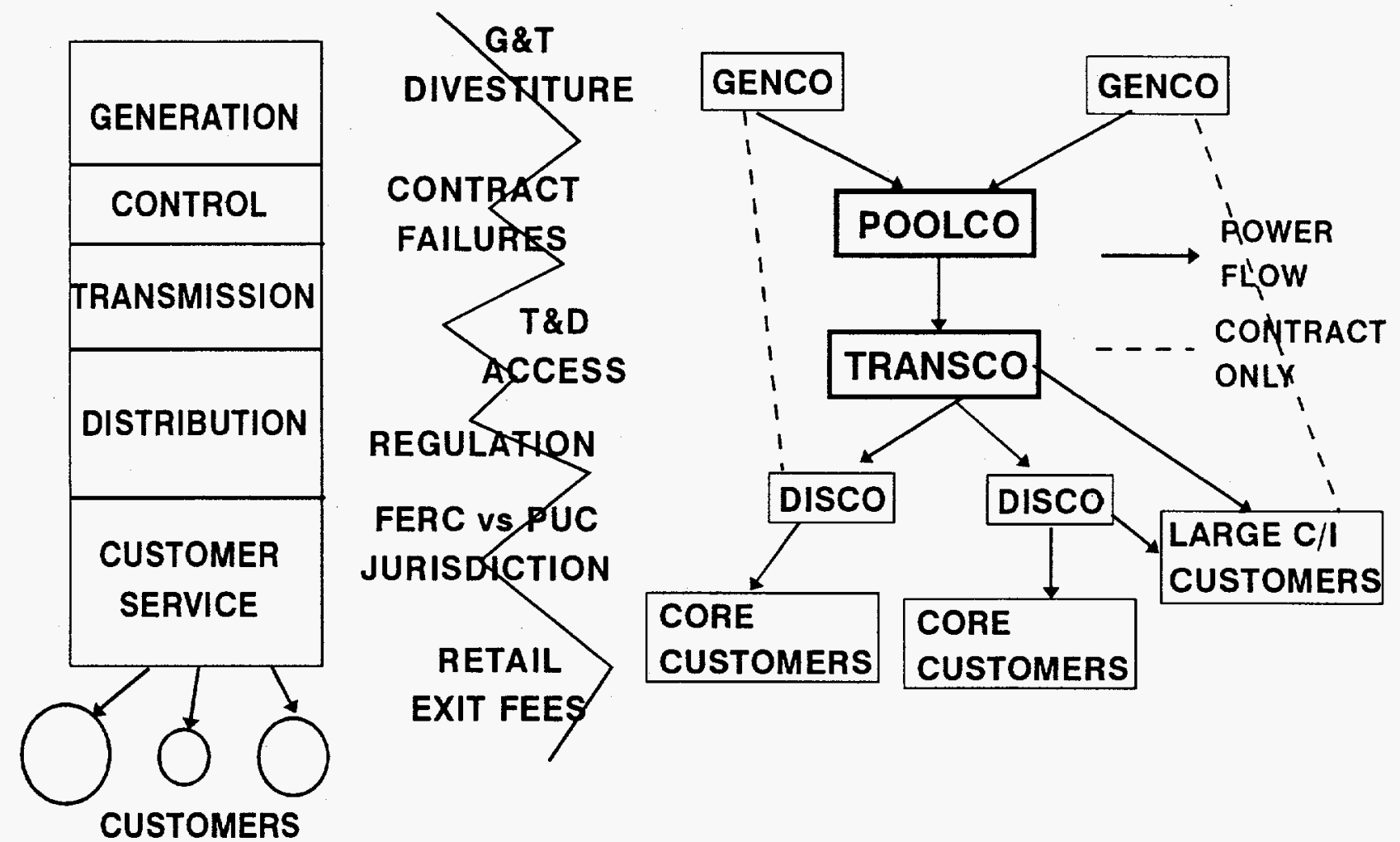

Fig. 3. Structure of electricity industry in which efforts to restructure and introduce competition fail. As noted in the text, failure can occur because of different technological, economic, and institutional reasons. (G\&T is generation and transmission and T\&D is transmission and distribution.)

One path to chaos could be found in the utilities' inability to compete with IPPs in the generation arena. Traditional utilities might continue to be heavily regulated by state PUCs. They would be subject to pressures from all the interest groups that have traditionally litigated against them in rate cases, IRP hearings, and other forums before state regulators. Thus, utilities (but not their competitors) would continue to bear various societal responsibilities related to IRP, environmental quality, renewable setasides, DSM programs, low-income assistance, and energy research and development (R\&D). On the other hand, IPPs would be free of most state regulation associated with IRP, although they would still be subject to environmental regulation. As a consequence, many IPPs could make and implement decisions and build power plants much more quickly and at lower cost than could utilities. This path leads to a decision point for utilities and regulators: compete with IPPs or divest utilities of their generation assets.

Regulators could fail to adapt to changing industry conditions. For example, they might not allow utilities to recover the true costs of transmission services by wrongly basing cost 
recovery on outdated notions of embedded costs. In addition, delays in the transmission-ratesetting process could render utilities unable to change rates as quickly as the market and their cost structures require, creating financial losses for utilities. Regulators could unfairly disallow utility expenses for activities undertaken during the heavily regulated regime that would not be considered in a competitive environment (e.g., expenses for now abandoned nuclear power plants and costs of DSM programs that did not return promised gains in energy efficiency). All these factors would add to utilities' financial constraints in their competition with IPPs and prompt a decision to compete or divest generation and transmission.

At the point where these two paths converge, many utilities could adopt a survival strategy, mixing the decision to compete with actions to ease regulatory burdens and to shape the regulatory process for benefit. Divestiture would be seen as undesirable because it would reduce the value of the company and its influence in the industry. Following this path, utilities might persuade regulators in some states that they cannot make available as much of their transmission systems as others would like to use and they must charge access fees that are so high that they eliminate most of the economic benefits derivable from retail wheeling. As a consequence, wholesale (and therefore retail) competition would be thwarted. In this situation, regulators would be faced with the need to regulate in a traditional fashion what is left of the integrated utility, and at the same time develop new regulatory frameworks for the emerging competitive industry.

In an alternative path, utilities might make it difficult for many large customers to leave their service area. Some PUCs might side with utilities in their bids to protect utility franchises and to reduce financial burdens posed by stranded investments. Thus, very high exit fees would be demanded from customers that seek to obtain their supplies elsewhere, as well as very high reentry fees for returning customers. Given uncertainties about whether the envisioned situation would fully arrive, many large customers might opt to stay with their local utility while lobbying for both traditional regulation of rates and easing of the constraints that bind them to their historical supplier of electricity. These lobbying efforts could further complicate the regulatory environment.

A third possible chaos path would have utilities cutting their operations and maintenance budgets sharply and deferring all T\&D investments that they possibly can. Utilities would do this because they worry that their higher costs will encourage customers to leave their systems and lead regulators to declare imprudent some of their investments in generation (i.e., these assets would become stranded). Although these actions (actually, inactions) would help to keep utility costs down in the short-term, within a few years customers would experience much more frequent and prolonged outages because of generation, transmission, and distribution failures. Industrial customers would worry about the reliability of power supplies; residential and commercial customers complain about outages. One can conceive of a major large-scale power interruption that provokes both regulators and customers to seriously consider returning to the monopolistic and regulated environment. 
In a fourth alternative, IPPs might fail to live up to their promise. IPPs might be unable to: (1) build plants on time and within budget, (2) site new plants because of citizen concerns, and (3) operate plants in a reliable and environmentally sound fashion. If the price of natural gas increases dramatically, many IPPs would become uncompetitive with utilities (which still have a diverse portfolio of resources). In combination, these factors could result in numerous IPP bankruptcies, forcing the abandonment of substantial supply resources. This excessive reliance on gas-fired generation could lead to rapidly increasing electricity prices, reliability problems, and blackouts. Citizen outrage would compel regulators to consider re-regulation, which if done halfheartedly would lead to additional fractures in the industry.

A fifth path is characterized by the regulators' inability to implement procedures for fair and equitable divestiture of utility generation and transmission assets. Thus, along this path, utilities would be forced to divest involuntarily. Utilities would stop building new plants. Contracts with IPPs would be difficult to secure because high levels of stranded investment would weaken the financial status of utilities. Power pools might form only slowly because many players have conflicts of interest. Serious conflicts might arise between federal and state regulators over divestiture of transmission assets and subsequent ownership and pricing arrangements. Like the other paths, regulators would again find themselves in very difficult situations.

The last path to be explored is in some sense the saddest. Regulators would solve the divestiture question, utilities would voluntarily divest, and IPPs would be reliable suppliers of power. Having cleared these hurdles, the industry would discover that the new institutions (GENCOs, POOLCOs, TRANSCOs, and DISCOs) cannot successfully carry out their responsibilities. Rules adopted to govern operation of POOLCOs turn out to be inefficient. In addition, POOLCOs, TRANSCOs, and DISCOs may be either too large or too small, ownership of GENCOs might be too concentrated, determining transmission charges could be complicated and controversial, and system reliability and planning could be neglected. Many of these problems could have been avoided if the parties had spent less time on transition issues and more time on forward thinking. Retrofitting the system would prove difficult as many have figured out ways to benefit from this badly designed competitive system and resist change. Things could become so convoluted, that citizens pressure regulators to turn the clock back, creating regulatory chaos.

Regardless of the path taken to chaos, there would be numerous adverse fallouts from these types of situations. The most obvious would be that competition does not reduce electricity prices. In addition, regulatory chaos could create a financial crisis for the electric industry. Access to capital on reasonable terms might be precluded, reflecting the high risks associated with this scenario. The potential exists for considerable stranded investment in uneconomical plants because short-run marginal costs are low. The absence of public policy on how to deal with stranded investments could also raise the cost of capital. 
Efficiency - either economic or energy-would not be improved. DSM benefits would not be realized because these programs were gutted as utilities (or DISCOs) pressed ahead to lower prices by every means possible. Renewables would be desired in the abstract, but utilities (or DISCOs) could not afford to acquire them, and IPPs would not build plants that use renewable energy. Regulators theoretically may be able to discern new methods to effectively promote both DSM and renewables but are understandably preoccupied with other serious regulatory questions.

The reduced investments in DSM and renewables could contribute to a general reduction in resource diversity. Fuel prices might escalate, in part because natural gas is virtually the only fuel used. Nuclear plants might be retired earlier than their scheduled lifetimes because of technical and economic reasons. Thus, the nation might again face energy-security problems.

The environment might not be safeguarded. Utilities might argue that paying for environmental programs would put them in uncompetitive situations-indicative of an uneven playing field--because other institutions would not be not required to internalize externalities. Attempts to force utilities to internalize externalities could break down in disputes between PUCs and legislatures as lobbyists argue that such measures threaten jobs and economic growth. Citizens might balk at increased taxes, erroneously thinking that utilities, rather than themselves, used to pay for environmental-protection programs.

Relationships among stakeholders could become adversarial, and institutional mistrust could run high. Cries of outrage might come from IPPs, customers (especially large industrials that stood to gain the most from retail competition), and the federal government (over failure to meet environmental, especially $\mathrm{CO}_{2}$-reduction, goals). These complaints would stimulate PUCs to investigate and declare imprudent some utility investments in generation. Customer and IPP complaints about utility abuse of its monopoly power over the T\&D system would further increase the hostility of PUC hearings. Utilities would complain, with justification, that they continue to face substantial "incumbent burdens" that their competitors are free of.

Institutional conflicts would abound. Tensions between levels of government would continue with FERC and the PUCs fighting about transmission access, siting, and pricing.

Social tensions would be played out in legislative-regulatory debates and interclass struggles between the public and large industrial customers. Ongoing debates about utilities as tax collectors could further sour the public mood. Some people might declare the issue to be a red herring to avoid accepting responsibility for deteriorating electrical services. Others might argue that funds to support societal programs should be shifted to the general tax system, but legislators would resist that shift.

Stakeholders would not be sure where they want to go, to push the system toward competition or back to regulation. Public participation would be robust, given all the outrage and 
complaining, but because of the chaos in the system, citizens might be ineffective in satisfying their concerns. A lack of vision on the objectives of the enterprise, short-term outlooks, the unwillingness to solve problems, grandstanding, the quest for political points, and traditional rivalries between communities and states, states and states, and states and the federal government would complete the description of this scenario.

\section{PLANNING AND RESEARCH ISSUES}

\section{Question 1. What factors necessitate an electric-industry planning function?}

The chaos scenarios present fundamental planning issues that must be resolved before one can even begin to address IRP. What types of planning make sense in a chaotic industry that lurches between regulation and competition? Should it be formal because of the large stakes involved, or must it be informal because of its large uncertainties? Can a faster, simpler, more flexible IRP model be developed to undertake resource planning, or are practitioners better advised to use refined scenario-driven analyses (to reflect the considerable uncertainties that deterministic planning cannot address)? Who now plans for the public-interest obligations that have traditionally been undertaken by the regulated, vertically integrated utility industry? How would the needs of low-income customers be met? How should DSM and renewables development and deployment continue to be accomplished? How can fuel and technology diversity be maintained? What is the proper point along the fracturing chain from generation to transmission to distribution at which these portfolio matters are best addressed? Who would be able to (and how would they) preserve a long-term perspective on industry planning? Should anyone worry about the level and balance of R\&D commitment (between demand and supply resources and between short- and long-term projects)?

The key factors that argue for planning in this scenario might include uncertainty, the need to revitalize and relegitimize the planning function, lack of access to capital markets for utilities and IPPs, environmental compliance, reliability, the need to establish goals and objectives of the electric industry, and the need to define the proper allocation of planning responsibilities between federal and state governments and to clarify institutional accountability.

Planning would be necessary to define the desired end point of the electricity enterprise and the needs, requirements, and limitations of each stakeholder. Unless there is consensus on the end point, it would be impossible to develop consensus on how to get there. And planning would need to define the data and information needs within this chaotic scenario. For example, DISCOs might need reliable and current data on market characteristics and the resource choice alternatives in this scenario.

IRP processes as they now exist could be considered too bureaucratic, slow, and inflexible to complete. IRP might need to be redefined to permit greater flexibility over shorter time periods, 
with periodic adjustments. Uncertainties might become so great that there are opportunities only for provisional, temporary planning thrusts based on frequent feedback from markets.

PUCs, with assistance from FERC, might need to lead the effort to rebuild a workable consensus about basic goals, missions, and responsibilities of the electric-industry enterprise. PUCs need to work with others to improve trust and build confidence among the stakeholders. The private sector needs to have regulatory uncertainty minimized so that it can develop its strategic plans to deal with the uncertainties it normally faces.

Governments may need to establish interim rules. These rules would implement federal requirements for wholesale markets as well as PUC efforts to implement retail competition. State regulators and legislators have to harmonize their purposes.

Planning (both by governments and private firms) would also need to define a competitively neutral way to distribute the burden of environmental costs on all participants and to define which entities would be responsible for resource-portfolio management on behalf of core customers.

Question 2. What factors in your scenario reduce the need for an electric-industry planning function?

Virtually none! Planning would be terribly important in this scenario to reduce uncertainty, to build trust, and to find ways toward workable consensus on ends and means. It cannot be left to markets to replace the planning function under this scenario. Depending on the path to chaos, it might not be possible to construct markets and those that are established may not work. Utilities would need information to meet continuing public-service responsibilities (unless relieved by PUCs of that responsibility).

Question 3. What factors in your scenario constrain the implementation of an electric-industry planning function?

Many of the same factors that require planning also constrain its implementation, including uncertainty, institutional breakdowns, lack of data (because stakeholders are reluctant to share information with others), the declining financial health of utilities, lack of clarity on which institutions are responsible for what functions, and the increasing difficulty of agreeing on appropriate environmental goals in a competitive electricity market.

Question 4. Given insights arising from discussions on the first three questions, what characteristics might an electric-industry planning function have in your scenario, if any?

Answering the questions about load and other forecasts, resource assessments, societal and environmental factors, and other issues associated with Question 4 is extremely difficult for 
the chaos scenario. In part, the difficulty arises because there are so many ways in which chaos can occur and in part because of the institutional mistrust and hostility that characterize this scenario. 


\section{RESEARCH AND POLICY-ANALYSIS QUESTIONS}

In addition to providing insights into the three scenarios described above, the workshop participants considered key questions for which answers are needed to implement a competitive electricity industry. Participants identified many important and challenging research and policyanalysis questions. Most of the questions extend beyond IRP to the heart of the electric industry of the future.

We organized the many questions that arose during the group discussions into 13 areas (Table 3). The questions are considered together, rather than scenario by scenario, because each group generally identified similar issues. The rest of this chapter explores common themes in each area across the scenarios.

Generation: The common theme here concerns POOLCOs. What are POOLCOs? Who determines and what are the POOLCO operating procedures (scheduling, dispatch, and control)? Who has access to the pool? How many POOLCOs are needed throughout the U.S? Is there an optimal size? Who owns them? How are prices set? Are power pools and POOLCOs different (one informal, the other a separate entity that dispatches all power plants in a certain area)? Is utility divestiture of generation and/or transmission assets necessary for a competitive and fair wholesale market? How will the amounts of stranded commitments (expensive generating units and purchase-power contracts) be calculated? What parties will bear these costs? Will GENCOs acquire so many resources (i.e., concentration of ownership) that wholesale markets will not be competitive? How will a futures market be designed and operated? What role will renewable resources play?

Transmission: Will transmission-system planning, operation, and reliability be sacrificed in the industry of the future? Who will own transmission assets? How will ownership of existing assets be valued and compensated? Who will make system-control decisions? To what extent will transmission services be unbundled, separately costed, and separately priced? How many TRANSCOs are needed, and what are the determining factors in this decision? What will be the operating and legal relationships between POOLCOs and TRANSCOs? Should they be geographically contiguous entities?

Distribution: What is a DISCO? Is there an optimal number? Should service territories be realigned to enhance economic efficiency? To what extent will distribution services be unbundled, separately costed, and separately priced? Will municipally owned DISCOs operate differently from privately owned DISCOs? 
Table 2. Summary of research and policy-analysis questions

\begin{tabular}{|c|c|c|c|}
\hline & Wholesale competition & Retail competition & Chaos \\
\hline Generation & \multicolumn{2}{|c|}{$\begin{array}{l}\text { Is divestiture of generation assets necessary for competitive wholesale markets? } \\
\text { Determine the optimal number, size, and ownership of POOLCOs } \\
\text { Examine POOLCO operation (e.g., who establishes the rules and what are the rules) } \\
\text { Determine the size of stranded commitments and appropriate allocation of costs }\end{array}$} & $\begin{array}{l}\text { Examine POOLCO management of } \\
\text { supply vs bilateral contracts } \\
\text { Evaluate whether the wholesale } \\
\text { generation market is competitive }\end{array}$ \\
\hline Transmission & \multicolumn{2}{|c|}{$\begin{array}{l}\text { Who should own, build, and plan transmission systems? } \\
\text { Determine the optimal sizes of TRANSCOs } \\
\text { What are the relationships among POOLCOs, TRANSCOs, and RTGs? } \\
\text { Analyze transmission services and their unbundled costs, and decide whether and } \\
\text { how to separately price these services }\end{array}$} & $\begin{array}{l}\text { Determine reasonable transmission } \\
\text { costs and prices } \\
\text { Determine how to evolve efficient } \\
\text { transmission pricing based upon } \\
\text { marginal costs }\end{array}$ \\
\hline Distribution & & \multicolumn{2}{|c|}{$\begin{array}{l}\text { Define DISCO functions } \\
\text { Determine the optimal number and sizes of DISCOs } \\
\text { Examine DISCO management of supply-and-demand- side portfolios } \\
\text { Examine whether the retail market is competitive and equitable in its treatment of } \\
\text { core and noncore customers }\end{array}$} \\
\hline Sỵstem-wide & $\begin{array}{l}\text { Should POOLCOs and TRANSCOs be } \\
\text { separate entities? Contiguous? } \\
\text { Evaluate the pros and cons of different } \\
\text { ownership schemes for GENCOs and } \\
\text { TRANSCOs }\end{array}$ & $\begin{array}{l}\text { Assess alternative approaches to } \\
\text { reliability (engineering vs pricing) } \\
\text { Should fire walls exist among GENCOs, } \\
\text { POOLCOs, and TRANSCOs? } \\
\text { Specify the distinction between } \\
\text { transmission and distribution } \\
\text { What entity should control system } \\
\text { reliability and load shedding? }\end{array}$ & $\begin{array}{l}\text { Assess the impacts of competition on } \\
\text { R\&D (e.g., focus, financial support, } \\
\text { timeframes, and organization) } \\
\text { Examine how industry issues can be } \\
\text { addressed coherently to achieve } \\
\text { efficiency and fairness }\end{array}$ \\
\hline
\end{tabular}




\begin{tabular}{|c|c|c|c|}
\hline & Wholesale competition & Retail competition & Chaos \\
\hline Societal & \multicolumn{2}{|c|}{$\begin{array}{l}\text { Examine pros and cons of a "wires tax" to fund societal programs (e.g., R\&D, low- } \\
\text { income programs, DSM, and renewable setasides) } \\
\text { What is the appropriate role for DSM and who should be responsible for it? } \\
\text { Assess trade-offs between price levels and volatility for different customer groups } \\
\text { Examine public acceptability of alternative industry structures and futures } \\
\text { Assess stakeholders" willingness to pay for "societal goods" through electric bills }\end{array}$} & $\begin{array}{l}\text { Create a process to determine the areas } \\
\text { of consensus among stakeholders on } \\
\text { important issues } \\
\text { Examine who is responsible for what } \\
\text { obligations }\end{array}$ \\
\hline Environmental & \multicolumn{2}{|c|}{$\begin{array}{l}\text { Assess methods to guide power-plant siting to meet environmental concerns } \\
\text { Examine how environmental risks and contingencies can be built into rates } \\
\text { Assess the possibility of states blocking siting of new power plants and transmission } \\
\text { lines }\end{array}$} & $\begin{array}{l}\text { Assess the implications of industry } \\
\text { operations on the environment } \\
\text { Evaluate competitively neutral ways of } \\
\text { distributing environmental costs }\end{array}$ \\
\hline Legal & $\begin{array}{l}\text { Determine whether utility divestiture of } \\
\text { generation and/or transmission assets } \\
\text { is required to achieve fair competition }\end{array}$ & $\begin{array}{l}\text { Determine how to achieve divestiture } \\
\text { fairly } \\
\text { Examine the effects of PBR on DISCO } \\
\text { finances and resource acquisitions }\end{array}$ & $\begin{array}{l}\text { Examine whether utilities should be } \\
\text { relieved of uneconomic power } \\
\text { contracts. If so, how to do so } \\
\text { equitably? }\end{array}$ \\
\hline $\begin{array}{l}\text { Managing } \\
\text { transition }\end{array}$ & $\begin{array}{l}\text { Evaluate factors that cause instability } \\
\text { (e.g., towards retail competition) }\end{array}$ & $\begin{array}{l}\text { Analyze industry structure and } \\
\text { operations from a broad societal } \\
\text { perspective }\end{array}$ & $\begin{array}{l}\text { Examine whether a transitional } \\
\text { regulatory framework is needed } \\
\text { Examine how to bring new technologies } \\
\text { to market }\end{array}$ \\
\hline
\end{tabular}




\begin{tabular}{|c|c|c|}
\hline & Wholesale competition & Chaos \\
\hline IRP & $\begin{array}{l}\text { How can the benefits of traditional IRP (long-term cost minimization, environmental } \\
\text { protection, resource diversity, and public participation) be maintained? } \\
\text { Should IRP focus more on increasing customer value and less on cost minimization? } \\
\text { Examine the role of RTGs in IRP } \\
\text { Assess how to make IRP more efficient and timely } \\
\text { Evaluate whether limiting IRP to DISCOs is reasonable } \\
\text { Assess whether increasing competition will decrease contention in IRP processes }\end{array}$ & $\begin{array}{l}\text { Develop IRP methods that are faster, } \\
\text { more flexible, more efficient, and } \\
\text { acceptable to the public } \\
\text { Track the ongoing status and evolution } \\
\text { of IRP }\end{array}$ \\
\hline DSM & $\begin{array}{l}\text { Assess the effects of different structures and ownership of generation and } \\
\text { transmission on DSM and renewables acquisition } \\
\text { Evaluate methods for measuring customer value } \\
\text { Determine the extent of market- and government-induced energy efficiency without } \\
\text { utility DSM (i.e., nonutility ways to acquire DSM resources) } \\
\text { Evaluate the extent of utility DSM without PUC pressure, including DSM as a } \\
\text { customer service vs DSM as a resource } \\
\text { Assess options to overcome the lost-revenue problem }\end{array}$ & $\begin{array}{l}\text { Assess effects of competition on DSM } \\
\text { and renewables deployment by } \\
\text { utilities and other entities } \\
\text { Evaluate incentives for efficiency }\end{array}$ \\
\hline $\begin{array}{l}\text { External } \\
\text { factors }\end{array}$ & \multicolumn{2}{|c|}{$\begin{array}{l}\text { Examine the influence of new supply, demand (including electrotechnologies), and information technologies on industry structure } \\
\text { Evaluate implications of global climate change and stricter pollution limits }\end{array}$} \\
\hline $\begin{array}{l}\text { Tools/data } \\
\text { needs }\end{array}$ & $\begin{array}{l}\text { Create industry-simulation tools } \\
\text { Collect data on unbundled generation, dispatch, transmission, and distribution costs } \\
\text { Develop decision-support systems to assist policy analysis and system operation } \\
\text { Collect case-study data on experiences with competition and transition } \\
\text { Collect end-use data and assess its accessibility under competition } \\
\text { Research the experiences of other industries that experienced regulatory changes } \\
\text { Identify services that could be unbundled and separately priced }\end{array}$ & $\begin{array}{l}\text { Develop contingency-based transition } \\
\text { planning models } \\
\text { Refine scenario analysis }\end{array}$ \\
\hline
\end{tabular}


System-wide Issues: How can the system be assembled to enhance overall efficiency and to satisfy societal considerations. Should GENCOs be prohibited from owning any other electricsystem assets? Similarly, should TRANSCOs and DISCOs be restricted in this way? Should POOLCOs be prohibited from owning any system assets at all? Who is responsible for overall system reliability and long-term system planning? Should these issues be left to the marketplace? What, if any, are the roles for FERC and PUCs?

Societal Issues: Will the industry continue to support low-income programs, R\&D, DSM, access to electricity services, price stability, and stakeholder involvement? Should the electricity industry provide these societal services, or should state and federal governments be responsible for their provision? What societal goods would be traded off for promises of lower electricity rates and a broader range of electricity services? What public-involvement processes can be used to allow stakeholders to make these trade-offs to supplement market forces? Should DSM be considered an electricity resource, a societal function, or a form of customer service? Will the benefits of competition be enjoyed equitably across all sectors of the population? How important is stranded investment and what are the different ways to compute those amounts?

Environmental quality: How can environmental goals be met in a competitive industry? Plant siting, which PUCs oversee today for utility-built plants, may become more difficult to guide to meet clean-air and local siting concerns as IPPs build more new plants. How can national environmental policies, such as those related to international treaty obligations, be linked to essentially state and local environmental issues and regulations concerning power plants?

Regulation: Who regulates (FERC or PUCs) which aspects of the new industry and how can intergovernmental conflicts be avoided? How might a wires tax be implemented, which regulator(s) would oversee it, how would the funds collected be disbursed and for what purposes? How will PBR work? How can gaming and untoward financial rewards be prevented when PBR is implemented? Will different states adopt such widely different approaches to rate regulation that the efficiency of buyer-seller transactions will be constrained?

Law: How will divestiture work, if at all? Will these types of legal issues delay evolution of the industry or lead to a chaos scenario? Will utilities be able to manage the contracting process? Will large contract commitments threaten their financial health? Will thinly capitalized DISCOs have to pay premiums for power and be limited in the length of contracts they can sign?

Managing Transition: Leading the industry to a stable future is desirable, but many factors might destabilize any envisioned industry structure. During a major transition, some decisions and activities must be undertaken before others. What decisions need to take precedence over others? Continuing analysis is needed to warn society of impending problems (e.g., potentially unintended and/or perverse consequences of pricing policies). 
IRP: IRP will likely survive, albeit in a significantly broader range of forms. The major questions pertain to how to make IRP more effective, efficient, timely, and focused on the right criteria. For example, should IRP focus on customer value instead of cost minimization, and if so, what is meant by customer value? Will IRP continue to promote, in any case, the long-term minimization of costs and environmental damages? Will IRP be needed to ensure resource diversity and to provide for public participation in energy decision making?

DSM: Will acquisition of DSM resources decline or change? Competitive pressures to reduce prices, combined with problems in existing regulation, such as lost revenue, might act to reduce DSM acquisition. Options to continue DSM programs (e.g., government codes and standards and utility programs to build alliances with customers) should be considered. So, too, should the possibility that DISCO programs focused on meeting customer needs (e.g., customer retention and assistance in improving customer productivity) will provide broader societal benefits, such as energy savings and demand reductions.

External Factors: The major external factor that could significantly influence the industry is technology, especially information technology. Another is global warming, which, if confirmed, will severely constrain current coal-plant operations and future construction of fossil-fuel plants. The industry should examine wild cards (e.g., global warming, war, and generation competition from Canadian and Mexican partners) that might cause additional changes.

Tools/Data Needs: Computer-based tools might be needed to assist decision makers in understanding the industry from a systems perspective. For example, if this policy were enacted, what would be the effect on reliability; and if reliability were affected, what would be the effect on prices? In addition, a general need for data was expressed, from examining unbundled costs to conducting case studies on experiences with competition and transition to investigating experiences of other countries and in other industries that have undergone significant regulatory change.

In summary, there are many important questions about the future of the electric industry. The extent and nature of the questions prompt several observations. First, stakeholders should maintain open dialogue on the questions. An institutional champion is needed to act as a neutral facilitator, mediator, and coordinator to ensure that interactions among stakeholders are constructive and equitable.

Second, a comprehensive research and policy-analysis effort is needed to inform all participants about the future of the industry. Data need to be collected and analyzed. Models need to be developed and deployed. Policy options need to be defined and evaluated. Data, models, and decision-support tools need to be shared among the stakeholders.

Third, planning of various types and at different levels is necessary. At the highest level, plans are needed to facilitate the dialogue mentioned above. As dialogue progresses, consensus 
will be required on the next steps in the transition process, which could be formulated as plans. In addition, continued system-wide planning and planning by utilities, IPPs, and the new institutions as they evolve are needed. IRP will likely be important in the short term, as utilities will still own the majority of generation and all of the T\&D assets. IRP will also be important in the wholesale-competition scenario with its emphasis shifting from acquiring specific resources to managing a portfolio of contracts with IPPs. IRP will change in the long term if the industry changes to the retail-competition scenario.

In conclusion, looking at this industry from a perspective of several generations in the future, one can argue that time and effort should be devoted to document how this industry struggles with the issues discussed above for the benefit of future industries and societies., Given the concerns expressed at the workshop, it is not certain that market forces will ultimately lead to a greater societal good than could be accomplished within revised regulatory structures. As depicted in the chaos scenario, the transition could go seriously awry. In any case, much could be learned if plans were made now to study the industry as it evolves.

\section{ACKNOWLEDGMENTS}

We appreciate all the work that Sheila Moore did in arranging the conference location and logistics. We thank Charles Augustine, Lee Barney, Eric Blank, Dave Boomsma, Michael Dworkin, Alan Destribats, Nancy Esteb, Paul Galen, Jeff Gleason, Chuck Goldman, Jan Hamrin, Cheryl Harrington, Joseph Hipius, Mary Ellen Hopkins, David Iliff, Bruce Larson, Andy Krantz, Jonathan Lowell, Ed Mayberry, Ron Parsons, Sonny Popowsky, Dan Quigley, Karl Rabago, Richard Rosen, Fred Schmidt, Don Schultz, and Charles Stalon for participating actively in the workshop and for offering helpful comments on the draft of this report. Without the energetic, enthusiastic, and intelligent participation from these 30 people, this report would not exist. We also thank Les Baxter, Paul Centolella, Randy Curlee, Joe Eto, Bruce Humphrey, and David Meyer for their comments on this report. We thank Fred O'Hara for editing this report and we thank Ethel Schorn for navigating the report through the ORNL clearance and publication processes. 



\section{APPENDIX A: WORKSHOP PARTICIPANTS}

Charles Augustine

Harvard University

Lee A. Barney

Portland General Electric

Douglas Bauer

Oak Ridge National Laboratory

Eric Blank

Land and Water Fund of the Rockies

David Boomsma

U.S. Department of Energy

Michael Dworkin

Vermont Public Service Board

Alan Destribats

Synergic Resources Corporation

Nancy Esteb

PacifiCorp

Paul Galen

National Renewable Energy Laboratory

Jeffrey Gleason

Southern Environmental Law Center

Charles A. Goldman

Lawrence Berkeley Laboratory

Jan Hamrin

Hansen, McOuat, Hamrin \& Rohde, Inc.

Cheryl Harrington

The Regulatory Assistance Project

Joseph J. Hipius

Niagara Mohawk Power Corporation

Eric Hirst

Oak Ridge National Laboratory
Mary Ellen Fitzpatrick Hopkins

Battelle, Pacific Northwest Laboratories

David Iliff

Wisconsin Public Service Commission

Bruce Larson

Illinois Commerce Commission

Andrew Krantz

U.S. Department of Energy

Jonathan B. Lowell

New England Power Service

Ed R. Mayberry

Potomac Electric Power Company

Ron Parsons

Alabama Power Company

Sonny Popowsky

Pennsylvania Office of Consumer Advocate

Dan Quigley

Pacific Gas and Electric Company

Karl Rabago

Texas Public Utility Commission

Richard A. Rosen

Tellus Institute

Fred Schmidt

Nevada Advocate for Customers of Public Utilities

Don Schultz

California Public Utilities Commission

Charles Stalon

Regulatory Consultant

Bruce Tomn

Oak Ridge National Laboratory 



\section{APPENDIX B: WORKSHOP AGENDA}

July 19, 1994

1:00 p.m. Registration

1:15 p.m. Welcome and Introductions

Eric Hirst, Oak Ridge National Laboratory

1:40 p.m. Historical Perspectives on Electric Utility Regulation

Doug Bauer, Oak Ridge National Laboratory

2:00 p.m. Discussion

2:45 p.m. The Electric Utility of the Future: Three Scenarios

Bruce Tonn, Oak Ridge National Laboratory

3:15 p.m. Discussion

3:45 p.m. Breakout Groups - Initial Discussions

5:15 p.m. Adjourn

July 20, 1994

8:45 a.m. Announcements

9:00 a.m. Breakout Groups - Proposal Exploration

10:45 a.m. Reports from Breakout Groups

11:30 a.m. Discussion

1:00 p.m. Breakout Groups - Developing a Research Agenda

3:00 p.m. Reports from Breakout Groups

3:45 p.m. Discussion

4:15 p.m. Wrapup - Eric Hirst

4:30 p.m. Close 